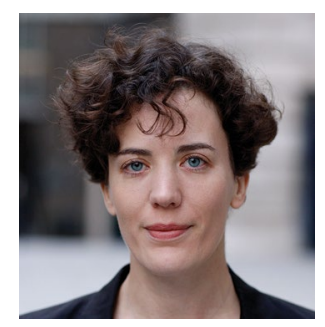

\title{
National elections in a globalizing world
}

\author{
National elections are an essential component of a democratic society. But, cautions Mareike \\ Kleine, elections can divert attention away from ongoing international negotiations, so their \\ timing should be carefully considered.
}

$\mathrm{R}$ egular free elections are a key feature of democracy. Citizens periodically get the chance to reward or punish their government for its performance and to choose a new direction for their country. National elections are essential for the functioning of democracies. However, they can be disruptive for international negotiations taking place at the same time. Election campaigns divert time and resources from the negotiations to the campaign trail, instil doubts about the future government's commitment to any deal, and keep governments from specifying their negotiation position on unpopular issues, out of fear that their electoral opponent at home will use it against them.

Research on the disruptive effect of national elections on international negotiations is challenging, as no two international negotiations are alike. They typically differ substantially, in terms of the interests represented at the negotiation table, the complexity of the issue and the negotiation's institutional context. An experimental approach is equally problematic, as we cannot simply randomize national elections to study their effect on an ongoing international negotiation.

Fortunately, the European Union (EU) turned out to be a close-to-ideal laboratory for our purposes. As an information-rich, permanent negotiation forum, it has for the past four decades produced a constant stream of independent agreements and data on many related factors. During the same time period, its exclusively democratic members held numerous elections that, bar a few exceptions, were held on fixed dates. In a survival analysis of the over 14,000 proposals for EU laws that were discussed between 1976 and 2006 (http://eprints.lse. ac.uk/67553/), we estimated the probability of a negotiation at the EU level being concluded at a given point in time, to gauge whether the chances of reaching conclusion decrease when the deliberations coincide with elections in one or more member states.

Our analysis yields a surprisingly large disruptive effect. In the case of elections to the German Bundestag, for example, the chances of reaching an agreement on an EU law in the 60 days before election day fell by as much as $60 \%$. At a general level, we find that close races and elections in large states were the most disruptive. We further estimate that in total, national elections might have delayed the introduction of laws by more than 6,000 years, compared with a situation without national elections. If we assume that EU laws are beneficial to European citizens, then this number signifies opportunity costs on a massive scale.

\section{National elections might have delayed the introduction of [EU] laws by more than 6,000 years.}

It would, of course, be absurd to infer from our research that national elections should be abolished for the sake of international cooperation; citizens' freedom to choose their own rulers is the hallmark of democratic government. We also caution against a crude generalization of our results beyond the EU context. The EU is special insofar as its enforcement mechanisms are stronger than those of most other international organizations, which suggests that its members are less concerned that new governments will fail to live up to their predecessors' commitments. What our research does indicate is that politicians would be well advised to be careful with the timing of elections and international negotiations, for they may waste valuable time.

Consider the Brexit negotiations between the United Kingdom and the 27 remaining EU members about the terms of the British withdrawal. The stakes for a successful and timely conclusion of the negotiations are high. In the event of a failure to reach an agreement, the EU treaties will automatically cease to apply to the United Kingdom, at which point it loses, among other things, access to the EU's single market, its customs union, and to the preferential trade agreements between the EU and several dozen other countries. The negotiations face strict time constraints, as in March 2017, Prime Minister Theresa May triggered Article 50 - the withdrawal clause - of the Treaty on European Union, which set off a two-year countdown within which the negotiations will have to be concluded.
In light of our research, it is no exaggeration to say that the timing of the trigger for Article 50 was unfortunate. It placed the first half of the negotiations in a year where no less than three large states Germany, France and the United Kingdom itself - as well as the Netherlands, held general or presidential elections. During this time, the politicians of these countries became preoccupied with the domestic arena, and the United Kingdom government failed to specify a reasonable negotiation stance. Although other factors are in play, it is still no surprise that almost one year into the talks (and with barely one year remaining), the Brexit talks have made little headway and are dangerously close to failing.

With the majority of the world's countries now governed by democratic regimes and the number of international organizations rising, it is important to ask whether - and how the disruptive potential of national elections can be dampened. One option would be to delegate negotiations to bureaucrats or conduct them in informal settings away from public scrutiny. However, this hardly solves the problem, as international agreements ultimately require executive decisions by democratically accountable members of government, and they still have an incentive to delay unpopular international agreements to eschew accountability at home. Another option would be for the large democratic members of an organization to coordinate the timing of their elections to limit the period of disruption, although this solution would face constitutional constraints. Meanwhile, the clock keeps ticking for the Brexit negotiations.

\section{Mareike Kleine}

European Institute, London School of Economics, London, UK.

e-mail:m.o.kleine@lse.ac.uk

Published online: 16 April 2018

https://doi.org/10.1038/s41562-018-0340-5

\section{Acknowledgements}

The research cited in this article was conducted jointly with C. Minaudier.

\section{Competing interests}

The author declares no competing interests. 